\title{
EXTROVERSION/INTROVERSION PERSONALITY TYPE AND LANGUAGE PROFICIENCY: A CASE STUDY OF IRAQI EFL UNIVERSITY STUDENTS
}

\author{
*Khalida Muhsen Hassan, ** Prof.Dr. Salam Hamid Abbas \\ University of Baghdad \\ College of Education/Ibn Rushd for Human Sciences
}

DOI: $10.37648 / \mathrm{ijrssh.v10i01.007}$

Received:29 ${ }^{\text {th }}$ September, 2019; Accepted:28th October, 2019; Published: $18^{\text {th }}$ November, 2019

\begin{abstract}
Personality is one of the most essential factors that have an impact on foreign language learning. Different personality types can be observed in students' developing different learning styles for themselves, which denotes the idea that there is a close connection between students' personality, and the style and the strategy that they develop to learn and succeed on the other. Extroversion / introversion, in particular, is one of four pairs of personality types which are reported to have a prior significance in language learning studies. Accordingly, foreign language teachers should know more about the students and increase their awareness of their students' personal differences in language classrooms. This will help them understand and appreciate the fact that individuals within a learning group may have different personality types and this requires the employment of varied classroom dynamics, activities, and strategies.
\end{abstract}

Key words: EFL, personality, extroversion/introversion, language proficiency

\section{SECTION ONE: INTRODUCTION}

\section{The Problem}

English language learning is a very complicated process in which learners have both generic (same for all learners) and specific (different individually) characteristics. Those structuralcharacteristics make their personal contributions to foreign language learning FLL process. Learner specific factors differentiate one individual from another in FLL.Learners usually range on some of the dimensions related to theirlearning style, age, language aptitude, persona, and motivation. Individual differences are anticipated to be essential for FLL since they determine how each person experiences his/her personal precise process of language learning. That is to say, learners' technique to language and the steps they take in the course of this process are supposed to be formed throughindividual variables, which have cognitive, social and affective aspects (Ellis, 1999:100). 
Being aware of student personality types in particular, teachers will be able to have a better understanding of the classroom dynamics and the ability to determine what kinds of classroom activities and strategies would be most effective with students in the class (Wilz, 2000:29). Concerning extroversion/introversion type of personality, some studies contendthat students with extrovert personality are better at learning a foreign language (Chastain,1975;Rossier,1975; Robinson et al.,1994; Brown et al.,1996;Hassan,2001) whereas the others defend the idea that there is no clear correlation between any personality trait and success in learning a second or foreign language (Suter,1976; Wilson \& Lyan,1990; Kim,1996; Wakamoto,2007; Sharp,2009; Soozandehfar et al, 2014).

Many studies report that Iraqi EFL university students are, generally speaking, have poor mastery of EFL and usually show weak performance in the different skills of language. Such deficiency leads to poor proficiency in English which is likely to hinder the development of their communication, presentation, classroom participation, and engagement (AlFahdawi,2014, AL-Jubouri, 2014).

The present study aims to find out examples of personality marking in language elements and skills, giving significance to extroversion and its counterpart, introversion, which are said to have an impact on the language learning process and learners' language proficiency.

However, the problem of this study is best expressed through answering the following questions:

1. Is there a relationship between extroversion / introversion personality trait and language proficiency?

2. Does extroversion / introversion personality trait contribute to student mastery of language skills?

\section{Aims}

The present study aims at
1. Finding out the dominance of extroversion/introversion personality trait of Iraqi EFL university students.

2. Finding out language proficiency of Iraqi EFL university students according to their extroversion/introversion personality trait.

3. Finding out The correlation between extroversion $\backslash$ introversion personality trait and language proficiency of Iraqi EFL university students.

\section{Value}

This study may be helpful in terms of determining the contributions of learner's personalities to their language proficiency. In addition, the results might be helpful for distinguishing how learners individually differ from each other and how these differences are reflected in their EFL mastery. This recognition may encourage teachers to provide appropriate settings for learners to actively participate in the EL learning activities. Learners, who differ from each other in the way they approach the task of language learning may also gain self-awareness in terms of the connection between their personality traits and language proficiency.

\section{Limits}

This study is limited to:

1. Iraqi EFL third year university students at the colleges of education.

2. the academic year 2018/2019.

\section{SECTION TWO: REVIEW OF LITERATURE}

\section{Personality and Language Learning}

The differences in personal characteristics that people owe would affect their lives and subsequently their ways of learning. Personality type is said to be the chief reason behind such variation. Very insightful is Carl Jung's perspective on personality in which he affirmed that what sounds to be random behavior is actually the result of people's different personal traits 
and preferences of using their mental abilities (Hull,1990:201).

Originally, the term "personality" is derived from persona, the Latin word, which means "mask", the "outward indication of a person's character". Personality, then, can be defined as a group of qualities which distinguishes one person from others. These qualities or characteristics work all together and are sometimes referred to as individual differences (Eysenck,2009:6).

A growing emphasis has been shown, in recent years, on the role of individual differences in foreign language learning. Learners' variation is very important factor affecting their ways of approaching foreign language learning. Two main dimensions are claimed to be affected by individual differences. The first one is the sequence or order in which linguistic knowledge is acquired. He explains that learners' differences in age, motivation, learning styles, aptitude, and personality would result in differences in the way along which learners would pass in FLL. The other important dimension is "the rate and ultimate success of FLL" (Ellis, 1990:99).

Fillmore (1979:204) has supported this claim and explains that while some people acquire a second language easily, and they succeed in achieving a degree of mastery over the new language, other people face difficulty in learning later languages. Fillmore (ibid:205) justifies such discrepancy among learners to their individual differences which in turn affect their success in FLL. Ellis (1990:102) argues that assuming the effect of individual differences on learning and competency rate is less problematic and controversial than assuming the effect of individual differences on the way of learning.

Many theories have been proposed to classify personality traits that people possess. Yet, within the last several decades, there has been an agreement among organization behavior researchers that the so-called fivefactor model of personality, also called the "big five"personality framework, is the most outstanding model in contemporary psychology(Apple,2011:15). Five_Factor Model (FFM) describes the most distinguished personality traits and it is defined as "a parsimonious and comprehensive framework of personality. The FFM collapses all personality traits into five broad factors and, as such, presents a concise yet comprehensive framework for studying personality" (Devaraj, et al., 2008: 93). Its dimensions are classified into: extraversion, agreeableness, conscientiousness, openness, and neuroticism.

\section{EXTROVERSION AND INTROVERSION}

In the fourth decade of the last century, Jung (1933) states that each person seems to be energized more by either the external world or the internal world (p. 211). The two complementary attitudes or orientations toward life described by Jung were known now as extroversion and introversion. Jung describes extroversion as an attitude in which the individual is oriented to the outer world of people and things, while, introversion is an attitude in which the individual is drawn to the inner world of thoughts and ideas (Gordon \&Yocke, 1999: 707).

In relation to personality traits, extroversionintroversion are terms that represent the way in which how individuals get stimulation and energy. Whereas extroverts recharge their batteries by being with people and to involve in high-energy events, introverts do this by drawing energy from within (Cain,2013: 26). Extraversion, however, "is normally characterized by an outgoing, candid, and accommodating nature that adapts easily to a given situation, quickly forms attachments, and, setting aside any possible misgivings, will often venture forth with careless confidence into unknown situations." (Kahnweiler, 2013:30). In the extroverted attitude, an individual's conscious orientation is determined by objective reality. In other words, external factors are the predominant motivating force for judgments, perceptions, feelings, affects and actions. The main characteristic of extraversion is the interest in the external things, readiness to accept external events, responsiveness, a tendency to be influential, a need to be with people and get with it, the influence of friends who are cultured, and finally a strong wish to help people (Jonkman, 2013: 93). Extroverts "need to experience the world to understand it; they tend to like a lot of activity" 
(Tieger\& Barron-Tieger, 1995:12).They usually appear much more social because they are eager for the stimulation that comes from meeting new people. They also tend to think and talk at the same time, and formulate their ideas best by saying them out loud (Parkash,et al,2016:2).

Generally speaking, extroversion has at least three basic characteristics that make it important to study. First, extroversion is regarded as one of the essential dimensions that has the ability to express the difference of a wide variety of behaviors, which is one of the central concerns for the field of personality (Funder, 2001:197). Second, extroversion predicts effective functioning and well-being across a wide range of domains from cognitive performance and social endeavors to social economic status (Roberts, et al, 2007: 313). Third, extroversion predicts risk and also flexibility for different forms of psychopathology (Widiger, 2005:67).

Introversion is exactly the opposite of extroversion. It is an attitude in which the distinguishing characteristic is that it finds its orientation in inner, personal factors. The introvert relates basically to the impressions aroused by the object in the subject; inner reality (McClain,1987:40). Introvert people are tuned in to their inner world with all its biases, illusions, dreams and individual perceptions (Feist, and Feist, 2008:122). Kahnweiler (2013) states that introverts process information internally, avoid showing emotion, keep matters private and exhibit calm nature (p.33). The introverts concentrate their energy and attention inward and need to understand the world before they experience it. They often prefer to spend time in smaller groups, or one-on-one, and usually like to get to know new people more slowly To others, introverts are notice to be shy or anti-social (Parkash, et al, 2016:2).

In brief, the introvert is more comfortable with the inner world of thoughts and feelings so that they will see the world in terms of its impacts upon them. While the extrovert feels more at home with the world of objects and other people and more interested with their impact upon the world (Chen, et al, 2015: 581).

\section{LANGUAGE PROFICIENCY}

In a foreign language, the concept of proficiency contains aspects of the ability to do something with the language ('knowing how') as well as knowing about it ('knowing what'). Accordingly, language proficiency involves communicative abilities of learner or user of a language, knowledge systems, and skills (Canale, 1983:45). One of the widely accepted definitions indicates that proficiency represents a learner ability to do or know as to the subject application in the real-life situation (Council of Europe 2001: 183).

Stern (1991:542) argues that the goal of foreign language teaching is to help learners of a language obtain proficiency in that language. For him the description and conceptualization of proficiency is an important phase in learning a foreign language. $\mathrm{He}$ suggests that language proficiency levels could be: elementary proficiency; limited working proficiency; minimum professional proficiency; full professional proficiency: and native or bilingual proficiency. He then mentions that language proficiency of a variety of foreign language learners "ranges from zero to nativelike proficiency. The zero is not absolute because the second language learner as the speaker of at least one other language, his first language, knows language and how it functions". Brumfit (1984:543) used fluency instead of proficiency and introduced it as, "the maximally effective operation of the language system so far acquired by the student".

Similar to the line of applied linguistic work, research is undertaken in the educational field and results in another way of conceptualizing proficiency, in terms of Communicative Academic Language proficiency (CALP) and Basic Interpersonal Communication Skills (BICS). CALP indicates academic knowledge and skills that are obtained or taught in formal schooling. Thus, it is a kind of proficiency that is necessary for accomplishing academic tasks such as comparing, contrasting, or evaluating, while BICS refers to the skills necessary for interacting with other people in daily situations. These two levels of proficiency indicates that proficiency at the school setting is a conscious or explicit mastery of 
language elements and language tests are prepared to evaluate proficiency in these terms (Claudia,2017:251).

Researchers view proficiency from two perspectives (Stern. 1983:343). The first one belongs to the different levels of proficiency dealing with the degrees of the actual or required mastery of the foreign language. These different levels of proficiency involves listening, speaking, reading and writing as shown in table (1). To develop proficiency in these skills, learners have to get access to fluent language models and opportunities, to practice intricate communicative situations, and to practice writing about different topics. Whereas the second perspective concentrates on the identification of the constituents of language proficiency, i.e, it views proficiency as several separate components. (Betty \& Boris, 2004: 12).

Table (1)

Language Proficiency Levels

\begin{tabular}{|c|c|c|c|c|}
\hline$\overline{\text { Level }}$ & Listening & Speaking & Reading & Writing \\
\hline 1 & $\begin{array}{l}\text { Understands social and } \\
\text { work demands and } \\
\text { concrete topics related } \\
\text { to interests }\end{array}$ & $\begin{array}{lr}\text { Satisfies } & \text { work } \\
\text { requirements } & \\
\text { with } & \text { usually } \\
\text { acceptable } & \text { and } \\
\text { effective } & \\
\text { language } & \end{array}$ & $\begin{array}{l}\text { Reads factual, non- } \\
\text { technical language, } \\
\text { grasping main and } \\
\text { subsidiary ideas }\end{array}$ & $\begin{array}{l}\text { Writes with some } \\
\text { precision and in } \\
\text { som e detail about } \\
\text { most common } \\
\text { topics }\end{array}$ \\
\hline 2 & $\begin{array}{l}\text { Understands all the } \\
\text { essentials of standard } \\
\text { speech, including } \\
\text { technical aspects of } \\
\text { professional field }\end{array}$ & \begin{tabular}{l}
\multicolumn{3}{l}{ Speaks with enough } \\
precision to \\
participate in \\
practical, social, \\
and professional \\
conversations
\end{tabular} & $\begin{array}{l}\text { Reads a variety of } \\
\text { authentic prose on } \\
\text { unfamiliar subjects } \\
\text { with near-complete } \\
\text { comprehension }\end{array}$ & 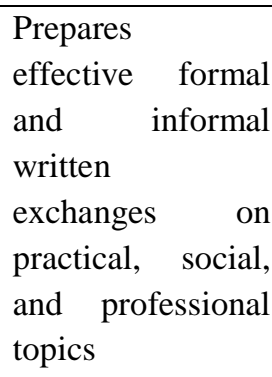 \\
\hline 3 & $\begin{array}{l}\text { Comprehends } r \text { forms } \\
\text { and styles of } \\
\text { pertinent } \\
\text { professional needs }\end{array}$ & $\begin{array}{l}\text { Accomplishes a } \\
\text { wide range of } \\
\text { sophisticated and } \\
\text { demanding } \\
\text { professional tasks }\end{array}$ & $\begin{array}{l}\text { Comprehends a } \\
\text { variety of styles and } \\
\text { forms pertinent to } \\
\text { professional needs }\end{array}$ & $\begin{array}{l}\text { Writes in a few } \\
\text { prose styles } \\
\text { pertinent to } \\
\text { professional and } \\
\text { education needs }\end{array}$ \\
\hline 4 & $\begin{array}{l}\text { Understands all forms } \\
\text { and styles of speech } \\
\text { pertinent } \\
\text { professional needs }\end{array}$ & $\begin{array}{l}\text { Speaks fluently and } \\
\text { accurately on all } \\
\text { levels pertinent to } \\
\text { professional needs }\end{array}$ & $\begin{array}{l}\text { Reads fluently and } \\
\text { accurately all forms } \\
\text { of language } \\
\text { pertinent to } \\
\text { professional needs }\end{array}$ & $\begin{array}{l}\text { Writes } \\
\text { professionally and } \\
\text { accurately in a } \\
\text { variety of prose } \\
\text { styles }\end{array}$ \\
\hline
\end{tabular}




\section{COMPONENTS OF LANGUAGE PROFICIENCY}

As far as ELT is concerned, studies have revealed that language proficiency involves all language areas. Lee and Schallert (1997:714) believed that language proficiency relates to learners ability to use language skills accurately in different contexts and situations. Otherwise, it refers to an individual's general knowledge of a given language involving grammar, vocabulary and discourse conventions which may be called upon during any instance of oral or written language use (Peregoy\& Boyle, 2008). Some researchers agree on the usefulness of the concept "ability" as an appropriate term to refer to "proficiency" since it can be seen as a middle ground between "competence" and "performance". Moreover, language "proficiency" is seen as related to the structural aspects of language. This may help both teachers and learners to establish their own stage of development in the teaching -learning process (Enric, 2000:90). Generally speaking, language proficiency are agreed upon to include listening, speaking, reading, writing, grammatical, and lexical components.

\section{SECTION THREE: METHODOLOGY}

\section{RESEARCH METHODOLOGY}

In this study, the descriptive-correlational type of research is adopted according to the nature of the study.

Table (2)

Sample Selection

\begin{tabular}{|l|l|l|l|}
\hline & $\begin{array}{l}\text { 3rd year EFL Students in } \\
\text { College of Education } \\
\text { Ibn Rushd for Human } \\
\text { Sciences }\end{array}$ & $\begin{array}{l}\text { 3rd year EFL Students } \\
\text { in College of Education } \\
\text { for Women }\end{array}$ & Total Number \\
\hline Total & 191 & 78 & 269 \\
\hline Sample & 170 & 77 & 247 \\
\hline
\end{tabular}

\section{INSTRUMENTS}

By reviewing related literature and previous studies and a set of scales that measure the extroversion/

\footnotetext{
and a set of scales that measure the extroversion/
}

This type is likely toprovide a basis for making predictions. Relationships among naturally occurring variables are assessed with the goal of identifying productive relationships.A correlation exists when two different measures of the same people, events or things vary together -that's when scores on one variable covary with scores on another variable(Shaughnesy, et al, 2006:144) .

\section{POPULATION AND SAMPLE}

The population in this study includes the students of the departments of English at the colleges of education in the Iraqi universities. The sample, on the other hand, is limited to EFL students of third year at the College of Education Ibn Rushd for Human Sciences and College of Education for women in the University of Baghdad. The reason for selecting third year students as the sample of this study is that these students have already completed about three years of studying English at their colleges. At this stage, students also should be mature enough to respond accurately to the personality scale and familiar enough with the four language skills to take the proficiency test. However, after excluding repeaters and primary school teachers on study leave, the total number of the sample is (247). See Table (2). introversion personality which are prepared for different age levels and categories, the Myers-Briggs Type Indicators (MBTI) scale is adopted in this study for being suitable to the sample and nature of the study. 
In order to measure students' proficiency as they use language skills (Reading, Listening, Writing, and Speaking), a proficiency test is constructed by the researchers.

\section{THE PERSONALITY SCALE}

The Myers -Briggs Type Indicator (MBTI) is an introspective self-report scale with the purpose of indicating the different personality traits according to the different psychological preferences in how people perceive the world around them and make decisions (Myers, 1980). The third edition of this tool which is released in 1998 has four sub-scales, ExtroversionIntroversion (E-I), Sensing-Intuiting $(\mathrm{S}-\mathrm{N})$, ThinkingFeeling (T-F), and Judging-Perceiving (J-P). According to the limits of this study, only the first sub-scale, extroversion-introversion is used. It consists of 40 items each item is followed by two alternatives, the first alternative measures the extroversion trait and the second one measures the introversion trait. The participants are entitled to choose one or both alternatives. On applying scoring scheme, the participants are given 1 score for the alternative that measures the extroversion, 2 scores for the alternative that measures the introversion, and zero if both variants are selected. Therefore, the scores achieved by participants are supposed to range between $(0-80)$.

\section{The Proficiency Test}

Information concerning the language proficiency of the learners can be attained through the use of tests, without which "it is difficult to see how rational educational decisions can be made "(Hughes, 1996:4).

The researchers develop a language proficiency test that contains four sections including listening comprehension (20 items to be scored out of 20), reading comprehension (10 items with a total score of 20), speaking (oral interview item to be scored out of 30 ) and writing (essay item with a total score of 30).

\section{Face Validity}

McNamara (2000:138) defines face validity of test instruments as "the extent to which a test meets the expectations of those involved in its use", i.e. test makers, administrators, teachers, and candidates. In the case of questionnaires or self-reported scales, face validity is the best type among other types of validity (Nunnaly, 1972: 323). Accordingly, the items of the scale should look right, and appear to measure what is supposed to measure, based on the examinees' subjective judgments, the administrators who manage it and the outside observers (Mousavi, 2002: 244)

In order to ensure the face validity of the instruments, the scale and the test, with its scoring rubric are exposed to a jury of experts. The jury consists of (16) specialists in TEFL and English Linguistics. They are asked to decide whether the items of the instruments are valid and proper for the sample and the aims of the study or not. However, all the items in both instruments have been approved by the jury members.

\section{Pilot Administration of the Instruments}

Pilot administration aims at gaining sufficient information on item functioning to assemble test forms (McDonough, 2011:206). To achieve this, 30 students are randomly selected from the third stage (College of Education /Al-Iraqia University) to represent the pilot sample. The pilot administrations of both the scale and test have been conducted to secure the clarity of scale and test items, estimate the time that the participants would need for responding to the scale and the test, and compute the reliability coefficients of both instruments.

According to the pilot administration, no ambiguity is reported in the items of the instruments. Moreover, the time that students need to respond to the extroversion-introversion scale is 40 minutes. While the time needed for proficiency test is found to be 20minutes for the listening part and 50 minutes for reading, and writing parts. Concerning the speaking part, 5 minutes time is found sufficient for testing each student.

\section{Construct Validity}

Construct validity includes logical and empirical analyses. It refers to the theoretical construct or trait being measured (Westen\& Rosenthal ,2003: 608).To 
achieve the construct validity of both the scale and the proficiency test, the psychometrics of the scale and the items of the test are examined by conducting an item analysis in which such aspects as item difficulty level, discrimination power, item-total correlation, and effectiveness of distracters in the multiple choice items of the test are checked and secured by using the suitable statistical procedures.

\section{Reliability}

Reliability refers to the degree to which the results obtained by a measurement and procedure can be replicated. (Rothman, 2008:128). It is defined as the extent to which a scale, test, observation or any measurement procedure produces the same results on repeated trials. In other words, it refers to the reproducibility or consistency of scores from one assessment to another (Cook and Beckman, 2006: 6).

To verify the reliability of the scale, the method of test-re-test is used in which the researchers readminister the scale to the pilot sample after two weeks of the first administration. The value of Pearson correlation coefficient of the scores of both administrations is calculated and found to be (0.857) which represents a good reliability coefficient according to Foran (1971:1123).
On the other hand, to verify the reliability of the test, Alpha-Cronbach method is utilized, the calculated reliability coefficient (0.839) is found accepted.

\section{Final Application}

The scale and proficiency test are administered to the study sample after ensuring their clarity, validity, and reliability. The students' responses are assigned marks according to the options they chose. After that, the data obtained is processed statistically by the use of the computer program (SPSS).

\section{SECTION FOUR : RESULTS, CONCLUSIONS, AND RECOMMENDATIONS}

\section{Results Related to the First Aim}

The first aim of this study reads "finding out the dominance of extroversion/introversion personality trait of Iraqi EFL university students".

After determining the number of students in each of the two traits according to the specific criterion, it is found that the percentage of extrovert students from the current sample is $33 \%$ of the total number While introverts represent a proportion of $(15 \%)$ as illustrated in the figure below.

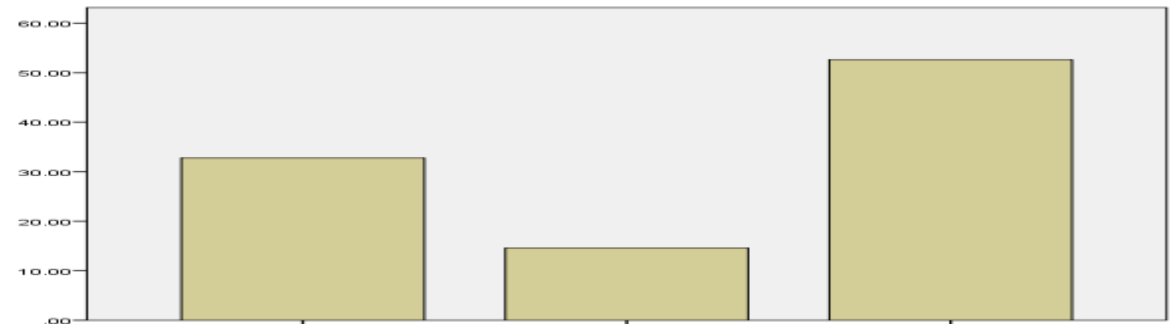

Extroverts introverts Ambiverts

Figure: Percentage of extroverts and introverts students' distribution

To investigate the statistical significance of the differences between the two groups of students, Chi- square is used. Calculated Chi-square value is found (19.208) which is higher than the tabulated one (3.84). The results are shown in table (3) indicates that there are statistically significant differences between the two groups and in favor of the extrovert group. 
Table (3) shows that among the (247) subjects ,81 are extroverts 36 are introverts. The rest of the sample (130 students) are found to be ambiverts, (also called intro-extro). These three categories account for 33\%, 15\%, and 52\% respectively. The last category is excluded due to the limits of the study.

Table (3)

The results of the Chi-square test to identify the significance of the differences between the extrovert and introvert students

\begin{tabular}{|c|c|c|c|c|c|}
\hline \multirow[t]{2}{*}{ Students } & \multirow[t]{2}{*}{ Number } & \multicolumn{2}{|c|}{ Chi-Square Value } & \multirow{2}{*}{$\begin{array}{ll}\text { Level } & \text { of } \\
\text { Significant }\end{array}$} & \multirow[t]{2}{*}{ Judgment } \\
\hline & & Calculated & Tabulated & & \\
\hline Extroverts & 81 & 19.208 & 3.84 & 0.05 & $\begin{array}{l}\text { significant } \\
\text { for Extroverts }\end{array}$ \\
\hline Introverts & 36 & & & & Students \\
\hline
\end{tabular}

\section{Results Related to the Second Aim}

To achieve the second aim of this study which is "finding out the language proficiency of Iraqi EFL university students according to their extroversion \introversion personality trait", T-Test for one sample is used to identify the significance of the statistical differences between the language proficiency of the extrovert students and their arithmetic mean. The results are shown in table (4).

Table ( 4)

Results of T-Test for one sample to identify the level of language proficiency EFL university extrovert students

\begin{tabular}{|l|l|l|l|l|l|l|l|}
\hline & Sample & Mean & $\begin{array}{l}\text { Standard } \\
\text { Deviation }\end{array}$ & $\begin{array}{l}\text { Arithmetic } \\
\text { Mean }\end{array}$ & \multicolumn{2}{|l|}{ T Value } & \multicolumn{2}{|l|}{$\begin{array}{l}\text { Significant } \\
(0.05)\end{array}$} \\
\cline { 4 - 7 } & & & & $\begin{array}{l}\text { Calculate } \\
\text { d }\end{array}$ & $\begin{array}{l}\text { Tabulat } \\
\text { ed }\end{array}$ \\
\hline $\begin{array}{l}\text { language } \\
\text { proficiency }\end{array}$ & $\mathbf{8 1}$ & 54.296 & $\mathbf{1 2 . 0 2 3}$ & 50 & 3.22 & 2 & Significant \\
\hline
\end{tabular}

It is clear from the results of table (4) that the calculated t-value of language proficiency is significant and this indicates that the extrovert university students have an accepted level of language proficiency.

As for introvert students, the results shown in table (5) indicate that t-value of language proficiency test is not significant. This finding indicates that the introvert university students have a low level of language proficiency. 
Table (5)

Results of T-Test for one sample to identify the level of language proficiency EFL university introverts students

\begin{tabular}{|c|c|c|c|c|c|c|c|}
\hline & \multirow[t]{2}{*}{ Sample } & \multirow[t]{2}{*}{ Mean } & \multirow{2}{*}{$\begin{array}{l}\text { Standard } \\
\text { Deviation }\end{array}$} & \multirow{2}{*}{$\begin{array}{l}\text { Arithmetic } \\
\text { Mean }\end{array}$} & \multicolumn{2}{|l|}{ T Value } & \multirow{2}{*}{$\begin{array}{l}\text { Significant } \\
(0.05)\end{array}$} \\
\hline & & & & & $\begin{array}{l}\text { Calculate } \\
\text { d }\end{array}$ & $\begin{array}{l}\text { Tabulat } \\
\text { ed }\end{array}$ & \\
\hline $\begin{array}{l}\text { language } \\
\text { proficiency }\end{array}$ & 36 & 48.361 & 11.258 & 50 & 0.873 & 2.021 & $\begin{array}{l}\text { Not } \\
\text { Significant }\end{array}$ \\
\hline
\end{tabular}

\section{Results Related to the Third Aim}

To achieve the third aim of this study which is "finding out the correlation between extroversion\introversion personality trait and language proficiency of Iraqi EFL university students", Pearson coefficient of correlation is used to calculate the correlation between extrovert students and their language proficiency. To verify the statistical significance of the calculated correlation coefficients, t-test is used to determine the statistical significance of the calculated correlation coefficients. The results are as shown in the table (6).

Table (6)

T-value for the significance of correlation coefficients calculated between extrovert students' degrees and their scores on language skills

\begin{tabular}{|c|c|c|c|c|c|c|}
\hline \multirow[t]{2}{*}{ Trait } & \multirow[t]{2}{*}{ Test } & \multirow{2}{*}{$\begin{array}{l}\text { Calculated } \\
\text { correlation } \\
\text { coefficient }\end{array}$} & \multicolumn{2}{|l|}{ T-Value } & \multirow{2}{*}{$\begin{array}{l}\text { Level of } \\
\text { Significance }\end{array}$} & \multirow[t]{2}{*}{ Judgment } \\
\hline & & & Calculated & Tabulated & & \\
\hline Extroversion & $\begin{array}{l}\text { Proficiency } \\
\text { test }\end{array}$ & 0.483 & 5.36 & 1.980 & 0.05 & Significant \\
\hline
\end{tabular}

It can be seen that the calculated t-value of the correlation between extroversion and language proficiency is statistically significant, indicating a real positive correlation between them.

With respect to the correlation between introversion and language proficiency, the results are shown in table (7) below.

Table (7)

T-value for the significance of correlation coefficients calculated between introvert students' degrees and their scores on language proficiency test

\begin{tabular}{|c|c|c|c|c|c|c|}
\hline \multirow[t]{2}{*}{\begin{tabular}{|l} 
Trait \\
\end{tabular}} & \multirow[t]{2}{*}{ Skill } & \multirow{2}{*}{$\begin{array}{l}\text { Calculated } \\
\text { correlation } \\
\text { coefficient }\end{array}$} & \multicolumn{2}{|l|}{ T-Value } & \multirow{2}{*}{$\begin{array}{l}\text { Level of } \\
\text { Significance }\end{array}$} & \multirow[t]{2}{*}{ Judgment } \\
\hline & & & Calculated & Tabulated & & \\
\hline Introversion & $\begin{array}{l}\text { proficiency } \\
\text { Test }\end{array}$ & 0.129 & 0.737 & 1.980 & 0.05 & $\begin{array}{l}\text { Not } \\
\text { Significant }\end{array}$ \\
\hline
\end{tabular}

The calculated t- value for the significance of correlation coefficients calculated between introversion and language proficiency is not statistically significant. This indicates that there is no real correlation between them. 


\section{DISCUSSION OF RESULTS}

The study findings indicate that the extroversion personality trait is significantly correlated with language proficiency, while introversion trait is not.

It is worth mentioning that the results related to language proficiency of students in each personality group are achieved according to their scores in the proficiency test which includes four parts; listening, speaking, reading, and writing .

As illustrated in the table (8) below, t-values of extrovert students' scores in the parts of the proficiency test listening, speaking, and reading are found statistically significant. It is not significant with regard to the writing part. This indicates that extrovert students have an accepted level of proficiency in speaking, reading, and writing but not in writing.

Table(8)

Results of T-Test for one sample to identify the level of language proficiency EFL university extroverts students

\begin{tabular}{|c|c|c|c|c|c|c|c|}
\hline \multirow[b]{2}{*}{ Test } & \multirow{2}{*}{$\begin{array}{l}\text { Sampl } \\
\text { e }\end{array}$} & \multirow[b]{2}{*}{ Mean } & \multirow{2}{*}{$\begin{array}{l}\text { Standard } \\
\text { Deviation }\end{array}$} & \multirow{2}{*}{$\begin{array}{l}\text { Arithmetic } \\
\text { Mean }\end{array}$} & \multicolumn{2}{|l|}{ T Value } & \multirow{2}{*}{$\begin{array}{l}\text { Significant } \\
(0.05)\end{array}$} \\
\hline & & & & & $\begin{array}{l}\text { Calculate } \\
\text { d }\end{array}$ & $\begin{array}{l}\text { Tabulat } \\
\text { ed }\end{array}$ & \\
\hline Writing & \multirow{4}{*}{81} & 12.852 & 6.448 & 15 & 3.96 & 2 & $\begin{array}{l}\text { Significant } \\
\text { for } \\
\text { arithmetic } \\
\text { mean }\end{array}$ \\
\hline Reading & & 11.086 & 3.302 & 10 & 2.961 & 2 & $\begin{array}{l}\text { Significant } \\
\text { for mean }\end{array}$ \\
\hline Listening & & 11.691 & 2.939 & 10 & 10.130 & 2 & $\begin{array}{l}\text { Significant } \\
\text { for mean }\end{array}$ \\
\hline Speaking & & 18.667 & 4.796 & 15 & 6.881 & 2 & $\begin{array}{l}\text { Significant } \\
\text { for mean }\end{array}$ \\
\hline
\end{tabular}

As for introvert students, the results show that t-values of their scores in the listening, speaking, and reading parts of the proficiency test are found statistically insignificant, and only that of writing is found significant. Accordingly, introvert students can be, generally speaking, judged to have a low level of language proficiency. See table (9).

Table (9)

Results of T-Test for one sample to identify the level of language proficiency EFL university introverts students

\begin{tabular}{|c|c|c|c|c|c|c|c|}
\hline \multirow[t]{2}{*}{ Test } & \multirow[t]{2}{*}{ Sample } & \multirow[t]{2}{*}{ Mean } & \multirow{2}{*}{$\begin{array}{l}\text { Standard } \\
\text { Deviation }\end{array}$} & \multirow{2}{*}{$\begin{array}{l}\text { Arithmetic } \\
\text { Mean }\end{array}$} & \multicolumn{2}{|l|}{ T Value } & \multirow{2}{*}{$\begin{array}{l}\text { Significance } \\
(0.05)\end{array}$} \\
\hline & & & & & $\begin{array}{l}\text { Calculate } \\
\text { d }\end{array}$ & $\begin{array}{l}\text { Tabulat } \\
\text { ed }\end{array}$ & \\
\hline Writing & & 17.278 & 3.896 & 15 & 3.50 & 2.021 & $\begin{array}{l}\text { Significant } \\
\text { for Mean }\end{array}$ \\
\hline
\end{tabular}




\begin{tabular}{|c|c|c|c|c|c|c|c|}
\hline Reading & 36 & 8.139 & 3.848 & 10 & 2.90 & 2.021 & $\begin{array}{l}\text { Significant } \\
\text { for arithmetic } \\
\text { mean }\end{array}$ \\
\hline Listening & & 7.000 & 3.033 & 10 & 5.934 & 2.021 & $\begin{array}{l}\text { Significant } \\
\text { for arithmetic } \\
\text { mean }\end{array}$ \\
\hline Speaking & & 12.944 & 5.806 & 15 & 2.124 & 2.021 & $\begin{array}{l}\text { Significant } \\
\text { for arithmetic } \\
\text { mean }\end{array}$ \\
\hline
\end{tabular}

Concerning the correlation aspects, the results reveal a significant correlation between extroversion and speaking, reading, and writing parts of the test. The results also indicate no correlation between extroversion and the listening proficiency test part. See table (10).

Table (10)

T-value for the significance of correlation coefficients calculated between extrovert students' degrees and their scores on language proficiency test

\begin{tabular}{|c|c|c|c|c|c|c|}
\hline \multirow[t]{2}{*}{ Trait } & \multirow[t]{2}{*}{ Skill } & \multirow{2}{*}{$\begin{array}{l}\text { Calculated } \\
\text { correlation } \\
\text { coefficient }\end{array}$} & \multicolumn{2}{|l|}{ T-Value } & \multirow{2}{*}{$\begin{array}{l}\text { Level of } \\
\text { Significance }\end{array}$} & \multirow[t]{2}{*}{ Judgment } \\
\hline & & & Calculated & Tabulated & & \\
\hline \multirow{4}{*}{ Extroversion } & Writing & 0.221 & 2.02 & 1.980 & 0.05 & Significant \\
\hline & Reading & 0.427 & 4.227 & 3.373 & 0.001 & Significant \\
\hline & Listening & 0.067 & 0.598 & 1.980 & 0.05 & $\begin{array}{l}\text { Not } \\
\text { Significant }\end{array}$ \\
\hline & Speaking & 0.249 & 2.305 & 1.980 & 0.05 & Significant \\
\hline
\end{tabular}

With respect to introversion students results, it is revealed that the correlations between introversion and listening, speaking, and reading parts of the test are insignificant, and only the one between introversion and the writing part is significant. See table (11).

Table (11)

T-value for the significance of correlation coefficients calculated between introvert students' degrees and their scores on language proficiency test

\begin{tabular}{|c|c|c|c|c|c|c|}
\hline \multirow{2}{*}{ Trait } & \multirow{2}{*}{ Skill } & \multirow{2}{*}{$\begin{array}{l}\text { Calculated } \\
\text { correlation } \\
\text { coefficient }\end{array}$} & \multicolumn{2}{|l|}{ T-Value } & \multirow{2}{*}{$\begin{array}{l}\text { Level of } \\
\text { Significance }\end{array}$} & \multirow{2}{*}{ Judgment } \\
\hline & & & Calculated & Tabulated & & \\
\hline \multirow{3}{*}{ Introversion } & Writing & 0.399 & 2.375 & 1.980 & 0.05 & Significant \\
\hline & Reading & 0.149 & 0.856 & 1.980 & 0.05 & $\begin{array}{l}\text { Not } \\
\text { Significant }\end{array}$ \\
\hline & Listening & 0.101 & 0.577 & 1.980 & 0.05 & Not \\
\hline
\end{tabular}




\begin{tabular}{|l|l|l|l|l|l|l|}
\hline & & & & & & Significant \\
\cline { 2 - 7 } & Speaking & 0.131 & 0.748 & 1.980 & 0.05 & $\begin{array}{l}\text { Not } \\
\text { Significant }\end{array}$ \\
\hline
\end{tabular}

The findings of this current study reveals that extroverts students have an accepted level in writing, speaking, and reading, indicating that there is a significant correlation between them whereas their level in listening is low, indicating that there is no correlation between them.

\section{CONCLUSIONS}

Through the findings of the current research, the following can be inferred:

1. The percentage of extrovert Iraqi EFL university students is almost double that of introvert students.

2. There is a significant statistical correlation between language proficiency and extrovert university students.

3. There is no statistically significant correlation between language proficiency and introvert university students.

4. There are statistically significant differences between the correlations of extroversion and introversion personality traits and language proficiency. This means that there is a correlational relationship between personality type and language proficiency.

\section{RECOMMENDATIONS}

In the light of the findings and conclusions, the following recommendations are offered:

1. More correlation studies are needed to build further support for clarifying the effect of personality traits on learning English as a foreign language. This type of studies, correlational ones, may help to see in what way and to what degree individual differences, introversion -introversion distinction, in particular, affect overall communication behaviors of learners. Such knowledge then can be used to adopt the language teaching methodology to the needs of learners of all kinds.

2. Being aware of learners' personality types, teachers are able to choose appropriate speaking and writing prompts. As extroverts show interest in thinking about the external world and their experiences, whereas, introverts prefer to reflect on their inner side. Thus, teachers are able to suggest choices of prompts by which each group of learners choose their favorite topics.

4. The administrators of English departments should have concrete plans to develop and monitor their students' English language proficiency in general. Also, they should establish bases and standards for allocating resources that contribute to the students' English language proficiency. Further, they should provide professional development assistance for the faculty to equip them relevant approaches, methods, strategies and techniques in English language teaching.

5. EFL classroom teachers should be sensitized to both types of extroversion and introversion among the university students. This may guide them to activate the guidance aspects for dealing with the introvert students.

6. Preparation programs of the departments of English at the colleges of education should target, in addition to developing students' language proficiency, promoting the positive aspects of personality and other important affective factors.

7. Finally, it is important to use more than one type of data collection instruments to investigate personality traits from different perspectives to 
(IJRSSH) 2020, Vol. No. 10, Issue No. I, Jan-Mar

achieve more reliable results due to the significance of such data for decision making.

\section{REFERENCES}

Ellis, R. (1999). Understanding second langauge acquisition.

Oxford:

Oxford University Press.

Wilz, B. (2000). Relationship between personality type and Grade Point Average of technical college students. Unpublished MA thesis, University of Wisconsin-Stout.

Chastain, K. (1975). Affective and ability factors in second-language acquisition. Language Learning, 25(1), 153-161.

Rossier, R. E. (1975). Extraversion-introversion as a significant variable in the learning of English as a second language: University of Southern California.

Robinson, D., Gabriel, N., \&Katchan, O. (1994). Personality and second language learning. Personality and Individual differences, 16(1), 143-157.

Brown, J. D., Robson, G., \&Rosenkjar, P. (1996). Personality, motivation, anxiety, strategies, and language proficiency of Japanese students. University of Hawai'i Working Papers in ESL, 15(1), 33-12.

Hassan, B. A. (2001). Extroversion/Introversion and gender in relation to the English pronunciation accuracy of Arabic speaking college students (Technical Report). Mansoura, Egypt: College Of Education, Mansoura University (ERIC Document Reproduction Service No. ED454740).

Suter, R. (1976). Predictors of pronunciation accuracy in second language learning. Language Learning, 26, 233-253. doi:10.1111/j.1467-

1770.1976.tb00275.x
e-ISSN: 2249-4642, p-ISSN: 2454-4671

Wilson, R. G., \& Lynn, R. (1990). Personality, intelligence components and foreign language attainment. Educational Psychology, 10, 57-71. doi:10.1080/0144341900100105

Kim, J. I. (1996). Personality variables and EFL proficiency among Korean elementary school students.UnpublishedPh.D Dissertation. University of Florida.

Wakamoto, N. (2007). The impact of extroversion/introversion and associated learner strategies on English language comprehension in a Japanese EFL setting: ProQuest.

Sharp, A. (2009). Personality and second language learning. Asian Social Science, 4(11), $\mathrm{p} 17$.

Soozandehfar, M., Soozandehfar, S. M. A., Farsi, M., \& Sharif, M.

(2014). Which Personality Trait Performs better on IELTS Speaking Test? Extroverted or Introverted?

Advances in Environmental Biology, 8(6).

AL-Jubouri , S. A. , (2014). The Relationship Between Iraqi EFL University Students' Self-Efficacy and Their Productive Skills' Performance.Unpublished MA Thesis. University of Baghdad.

Eysenck, H. J. (2009). The biological bases of personality\ Hans, J. Eysenck; new preface by Isybil B. G. Eysenck. Transcation Publishers, New Brunswick, New Jersey.

Ellis, R. (1999). Understanding second langauge acquisition. Oxford: Oxford University Press.

Fillmore, L. W. (1979). Individual differences in second language acquisition. InC. Fillmore, D. 
Kempler, and S. William, (Eds.), Indiviual differences in language ability and language behavior (203228). Newyork: Academic Press.

Al- Fahdawi, S.,(2014). The Relationship between Iraqi EFL University Students'Learning Styles, Motivation, Multiple Intelligence, and Proficiency. Unpublished Ph.D. dissertation. University of Baghdad.

Devaraj, S., Easley, R. F., \&Crant, M. J. (2008). How does personality matter? relating the five-factor model to technology acceptance and use. Information Systems Research, 19(1), 93-105. doi: $10.1287 /$ isre. 1070.0153

Jung, C. G. (1933). Psychological types. New York: Harcourt, Brace and World.

Gordon, H.R.D. and Yocke,R.,(1999). Relationship Between Personality Characteristics and Observable Teaching Effectiveness of Selected Beginning Career and Technical Education Teachers. Journal of Career and Technical Education,16(1).

Cain, S. (2013). Quiet: The Power of Introverts in a World That Can't Stop Talking. 1st paper back ed. United States of America: Broadway Books.

Kahnweiler, J. B., 2013. Quiet Influence. 1 ed. San Francisco: Berrett-Koehler Publishers, Inc.

Jonkman, L., 2013. Introvert Den TystaRevolutionen. 1 ed. Falun: Bokförlaget Forum.

Tieger, P. D., \& Barron-Tieger, B. (1995). Do what you are - discover the perfect career for you through the secrets of personality type (2nd ed.). New York: Little, Brown and Company
Funder, D. C. (2001). Personality. Annual Review of Psychology, 52, 197-221

Roberts, B. W., Kuncel, N. R., Shiner, R., Caspi, A., \& Goldberg, L. R. (2007). The power of personality: The comparative validity of personality traits, socioeconomic status, and cognitive ability for predicting important life outcomes. Perspectives on Psychological Science, 2 (4), 313-345.

Widiger, T. A. (2005). Five factor model of personality disorder: Integrating science and practice. Journal of Research in Personality, 39 (1), 67-83.

McClain, C. R. (1987). The relationship between personality characteristics and teaching effectiveness of secondary vocational agriculture teachers.Unpublished doctoral dissertation, University of Nebraska, Lincoln.

Feist, Jess, Gregory J. Feist. 2008. Theories of PersonalitySeventh Edition. USA: McGraw Hill Higher Education.

Chen, Y.,Jiang,Y.,Mu,Z., (2015). A Survey Study: The Correlation between Introversion/Extroversion and Oral English Learning Outcome. Journal of Language Teaching and Research, Vol. 6, No. 3, pp. 581-587

Canale, M. (1983). On Some Dimensions of Language Proficiency. In J.W.Oller : Issues in Language Testing Research. MA: Newburry House, 42-333.

Council of Europe. 2001. A Common European Framework of Reference for Language Learning and Teaching. Cambridge: Cambridge University Press.

Stern, H.H. (1991). Fundamental Concepts of Language Teaching. Hong Kong: Oxford University Press 
Brumfit, C. (1984). Communicative methodology in language teaching. Cambridge: Cambridge University Press.

Claudia, H., (2017). Proficiency.ELT Journal,71 (2),pp.250-253

Stern, H.H. (1983). Fundamental Concepts of Language Teaching. UK: Oxford University Press

Betty,L. and Boris S. (2004). Developing ProfessionalLevel Language Profeciency. Cambridge: Cambridge University Press.

Lee, J. and Schallert, D. L. (1997). The Relative Contribution of L2 Language Proficiency and L1 Reading Ability to L2 Reading Performance: A Test of the Threshold Hypothesis in an EFL Context. TESOL Quarterly, 31(4), 713739.

Peregoy, S. F., \& Boyle, O. F. (2008). Reading, Writing, and Learning in ESL: A Resource Book for K-12 Teachers (5th ed.). New York, NY: Addison-Wesley.

Enric, L. (2000). On Competence, Proficiency, and Communicative Language Ability. In The International Journal of Applied Linguistics, 10, (1), 85-93. Spain: University of Lleida.

Shaughnessy, J. ,Zechmerster, E. ,and Zechmerster, J.(2006). Research Method Personality.( $7^{\text {th }} \quad$ ed.).New York:McGraw-Hill.Slagoski. .

Myers, Isabel Briggs (1980). Gifts Differing:Understanding Personality Type.Davies-Black publishing, Reprint edition (May 1,1995). ISBN 0-89106074-X

Hughes, A. (1996). Testing for Language Teachers. Cambridge: Cambridge University Press.
McNamara, Tim. (2000) Language Testing. Oxford University Press.

Nunnally, Jum G. (1972). Education Measurement. New Jersey: Prentice Hall, Inc.

Mousavi, Seyyed Abbas. (1999):A Dictionary of Language Testing. Iran. Rahnama Publications.

McDonough, L. G, (2011).Self-assessment: Keeping a language learning log. In James Dean Brown(ED), New ways of Classroom Assessment (pp.206-208).Alexanderia, VA: Teachers of English to Speakers of Other Languages.

Westen, Drew\& Robert Rosenthal (2003) "Quantifying Construct Validity: Two Simple Measures." Journal of Personality and Social Psychology, 84( 3),608-618.

Rothman KJ, Greenland S, Lash TL (2008). Modern Epidemiology. Philadelphia, USA: Lippincott William and Wilkins; 2008. p. $128-47$.

Cook, A.D. and Beckman, J. T. (2006) Current Concepts in Validity and Reliability for Psychometric Instruments: Theory and

Application. The American Journal of Medicine 119,

166.e7-166.e16.

Foran, T.(1971). Social intelligence; Concept in search of Data. Psychological Report,Vol.29,1123. 